\author{
O.I. Nakonechna, M.M. Dashevskyi, A.M. Kurylyuk, N.N. Belyavina
}

\title{
Mechanochemical synthesis of $\mathrm{Co}_{3} \mathrm{C}$ carbide with carbon nanotubes
}

\author{
Department of Physics, Taras Shevchenko National university of Kyiv, 64/13 Volodymyrska Str., 01601, \\ Kyiv, Ukraine,e-mail: les@univ.kiev.ua
}

\begin{abstract}
Nanoscaled (about $15 \mathrm{~nm}$ of size) metastable carbide $\mathrm{Co}_{3} \mathrm{C}$ was synthesized in a high-energy planetary ball mill by mechanical alloying of a mixture of powder cobalt (75 at. \%) and multiwalled carbon nanotubes (CNT, 25 at. \%). Phase transformation takes place at reaction milling according to the reaction $h c p-\mathrm{Co}+\mathrm{CNT} \rightarrow \mathrm{Co}_{3} \mathrm{C}$ (reaction time is $120-220 \mathrm{~min}$ ). The crystal structure of the $\mathrm{Co}_{3} \mathrm{C}$ carbide formed in the milling products was studied by X-ray diffraction method. It has revealed that the $\mathrm{Co}_{3} \mathrm{C}$ phase crystallizes in a $\mathrm{Fe}_{3} \mathrm{C}$-type structure with $a=0.4982(3) \mathrm{nm}, b=0.6715(6) \mathrm{nm}, c=0.4457(7) \mathrm{nm}$, Pnma space group. The reliability factor $R_{B}$ is equal to 0.065 for 48 reflections presented at diffraction pattern. It is found that the crystal structure of the $\mathrm{Co}_{3} \mathrm{C}$ carbide obtained by reaction milling of the Co-CNT charge is significantly internally deformed (distortion degree of the $\mathrm{CCO}_{6}$ octahedron is $3.67 \%$ ) and contains the reduced interatomic Co-C distances (up to $0.188 \mathrm{~nm}$ ). It was shown that the use of carbon nanotubes instead of graphite substantially reduces the duration of the $\mathrm{Co}_{3} \mathrm{C}$ carbide synthesis.
\end{abstract}

Key words: multiwalled carbon nanotube; cobalt; X-ray diffraction; mechanochemical synthesis.

Article acted received 11.02.2019; accepted for publication 15.03.2019.

\section{Introduction}

Recently, nanomaterials are increasingly used to modify the structure of metals and alloys in order to obtain their higher physical and mechanical characteristics, which will reduce the weight of products from them while maintaining the necessary complex of properties. In particular, much attention is paid to the use of ultrafine powders of chemical compounds (carbides, nitrides, carbonitrides, etc.) in the production of new materials and alloys, as well as the carbon nanotubes. A special place among such compounds belongs to cobalt carbide, which is widely used in various industries, agriculture and medicine. $\mathrm{Co}_{3} \mathrm{C}$ is used as a dopant in refractory alloys for aviation engineering, electrical engineering and nuclear industry, in rocket building.

For the first time the metastable $\mathrm{Co}_{3} \mathrm{C}\left(\mathrm{Fe}_{3} \mathrm{C}\right.$-type structure) and $\mathrm{Co}_{2} \mathrm{C}\left(\mathrm{CaCl}_{2}\right)$ carbides were synthesized in thin films, which are formed on a heated up to $550{ }^{\circ} \mathrm{C}$ substrate under cobalt evaporation in $\mathrm{CO}+\mathrm{H}_{2}$ gas mixture [1]. Subsequently, these carbides were obtained mainly by cobalt carbidation, which was carried out either at the precipitation in thin films, or by the direct Fischer-Tropsch synthesis in a $\mathrm{CO}+\mathrm{H}_{2}$ gas atmosphere [2-6].

As is known, the reaction milling is one of the effective methods for obtaining a material in a nanoscaled state. Using this method Authors of Ref. [7] have synthesized the $\mathrm{Co}_{3} \mathrm{C}$ compound in a planetary ball mill by processing the cobalt and graphite powder mixture.

The aim of this work is to synthesize $\mathrm{Co}_{3} \mathrm{C}$ carbide in a high-energy planetary ball mill from cobalt and multiwalled carbon nanotubes (CNT) powder charge.

\section{Experimental details}

A charge containing 75 at. \% Co (99.8 wt. \% purity, particle size is about $80 \mu$ ) and 25 at. \% CNT was prepared for processing in a ball mill. Multiwalled carbon nanotubes used in this study were synthesized by the catalytic chemical vapor deposition method (CVD) at TM Spetzmash Ltd (Kyiv, Ukraine) [8]. The physical properties of the CNTs are as follows: the average diameter is $(10-20) \mathrm{nm}$, the specific surface area (determined by argon desorption method) is (200 $400) \mathrm{m}^{2} / \mathrm{g}$ and their bulk density varies from 20 to $40 \mathrm{~g} / \mathrm{dm}^{3}$.

The powder mixture prepared was sealed in a steel vial under an argon atmosphere and processed at room temperature in a high-energy ball mill [9]. Hardened stainless steel balls (15 units of $15 \mathrm{~mm}$ diameter) and a vial $(70 \mathrm{~mm}$ height, $50 \mathrm{~mm}$ diameter) with a ball-topowder weight ratio of 20:1 were used. The vial 
temperature was held at below $375 \mathrm{~K}$ during the experiments by air cooling. The milling process was cyclic with $5 \mathrm{~min}$ of treatment and $25 \mathrm{~min}$ of cooling time. The rotation speed was equal to $1480 \mathrm{rpm}$; the acceleration was about $50 \mathrm{~g}$ : the pressure for a substance particle reached $5 \mathrm{GPa}$.

The XRD study of phase transformations occurring at reaction milling of the initial mixture was performed with DRON-4 automatic discractometer (CoK $\alpha$ radiation) in a discrete mode: the scanning interval $2 \theta=$ (30-130 $)^{\circ}$, the step scan $0.05^{\circ}$, counting time per step was 3 s. An original software package including a complete set of standard Rietveld procedures was applied for the analysis and interpretation of the X-Ray data obtained (more details on www.x-ray.univ.kiev.ua).

\section{Results and Discussion}

According to the results of XRD phase analysis the sample selected after 60 min of processing contains the reflections of hexagonal cobalt with $a=0.2508(5) \mathrm{nm}$, $c=0.4076(4) \mathrm{nm}$. These lattice constants are somewhat higher than those for initial cobalt powder, namely, $a=0.2507(2) \mathrm{nm}$ and $c=0.40694(4) \mathrm{nm}$. The diffraction patterns of the test samples selected after of $120 \mathrm{~min}$ of the initial charge processing already contain reflections of the $\mathrm{Co}_{3} \mathrm{C}$ phase in addition to the reflections of hexagonal cobalt. Amount of this carbide is gradually increased and after $180 \mathrm{~min}$ of processing the $\mathrm{Co}_{3} \mathrm{C}$ carbide becomes the main phase of test samples. Indeed, diffraction pattern of the test sample selected after 220 min of processing (Fig. 1) contains reflections of the $\mathrm{Co}_{3} \mathrm{C}$ carbide with a small additional amount of hexagonal cobalt phase, which is strongly textured in the (002) direction (the reflections of this additional phase are marked as "x" at Fig. 1).
It should also be noted that all reflections on the diffraction patterns of the test samples are highly broadened (Fig. 1). And this gives us an opportunity to estimate the average crystallite size by the classic Williamson-Hall plot. So, it was found that the $\mathrm{Co}_{3} \mathrm{C}$ carbide obtained by reaction milling of the Co-CNT charge is a nanoscaled phase with average grain size of $15 \mathrm{~nm}$.

Refinement of the crystalline structure parameters, including atomic coordinates, filling of corresponding atomic positions and temperature parameters, was carried out for $\mathrm{Co}_{3} \mathrm{C}$ carbide within the framework of the $\mathrm{Fe}_{3} \mathrm{C}$-type structure, where the values given for the $\mathrm{Co}_{3} \mathrm{C}$ carbide in Ref. [1] were taken as reference data. Besides, considering the fact that refinement of the $\mathrm{Co}_{3} \mathrm{C}$ carbide crystal structure was provided for a sample containing a small amount of the additional cobalt the coordinates of the carbon atoms were committed and just the position of metal atoms was varied.

As a result of calculations fulfilled for the $\mathrm{Co}_{3} \mathrm{C}$ carbide synthesized by the mechanical alloying of the Co-CNT charge (Table 1), it was shown that cobalt atoms are substantially displaced from the positions inherent to the similar atoms in the structure of the $\mathrm{Co}_{3} \mathrm{C}$ carbide obtained by another way. Moreover, its crystal lattice is about $2 \%$ more compact, namely, $a=0.4982$ (3) $\mathrm{nm}, b=0.6155(6) \mathrm{nm}, c=0.4457(7) \mathrm{nm}, V=0.1491$ (2) $\mathrm{nm}^{3}$ for the $\mathrm{Co}_{3} \mathrm{C}$ carbide synthesized by mechanical alloying of Co-CNT mixture; $a=0.5033 \mathrm{~nm}, \quad b=$ $0.6731 \mathrm{~nm}, c=0.4483 \mathrm{~nm}, V=0.1519 \mathrm{~nm}^{3}$ for the $\mathrm{Co}_{3} \mathrm{C}$ carbide synthesized in thin films [1]. It should be noted that, unfortunately, the Authors of Ref. [7] did not refined the lattice constants of the $\mathrm{Co}_{3} \mathrm{C}$ carbide

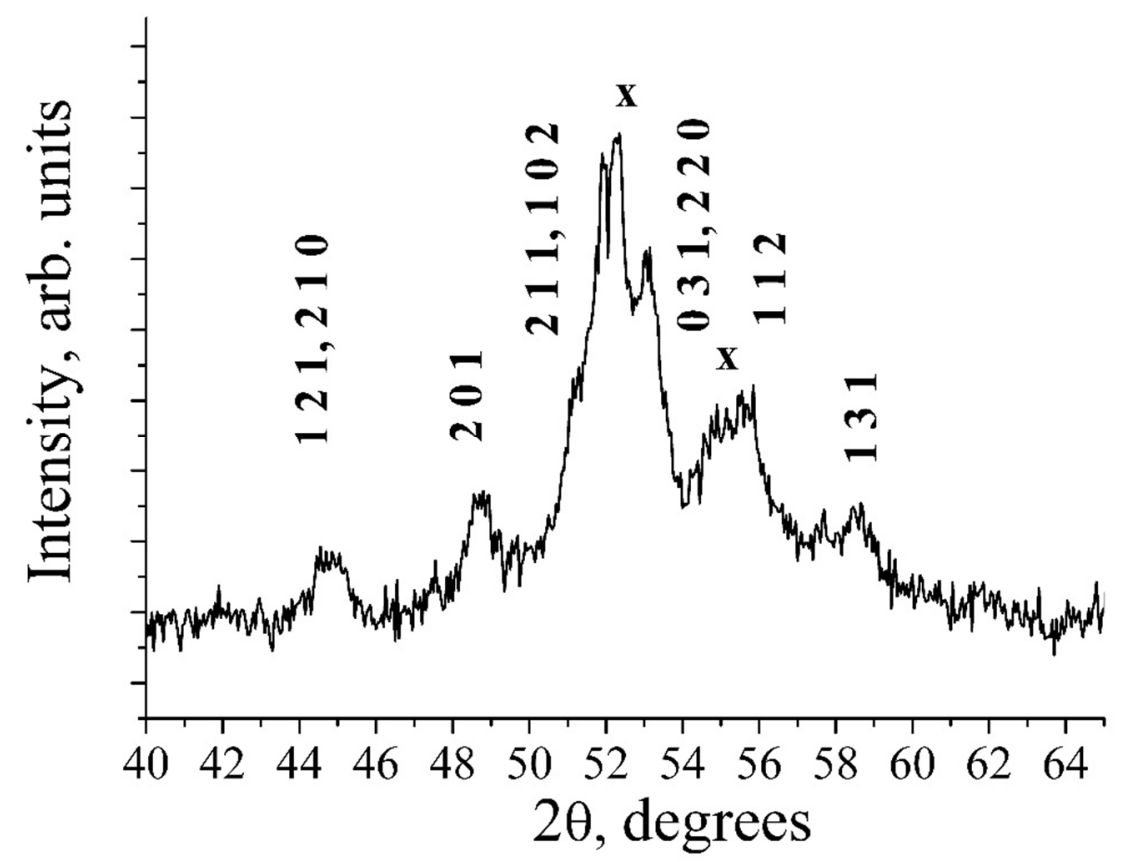

Fig. 1. Diffraction pattern of Co-CNT charge processed in a planetary ball mill for $220 \mathrm{~min}$. The textured hcp-Co phase is marked as ' $\mathrm{x}$ '. 
Table 1

Rietveld X-ray powder diffraction data for the crystal structure of the $\mathrm{Co}_{3} \mathrm{C}$ carbide (space group Pnma, $\mathrm{No}=62$ )

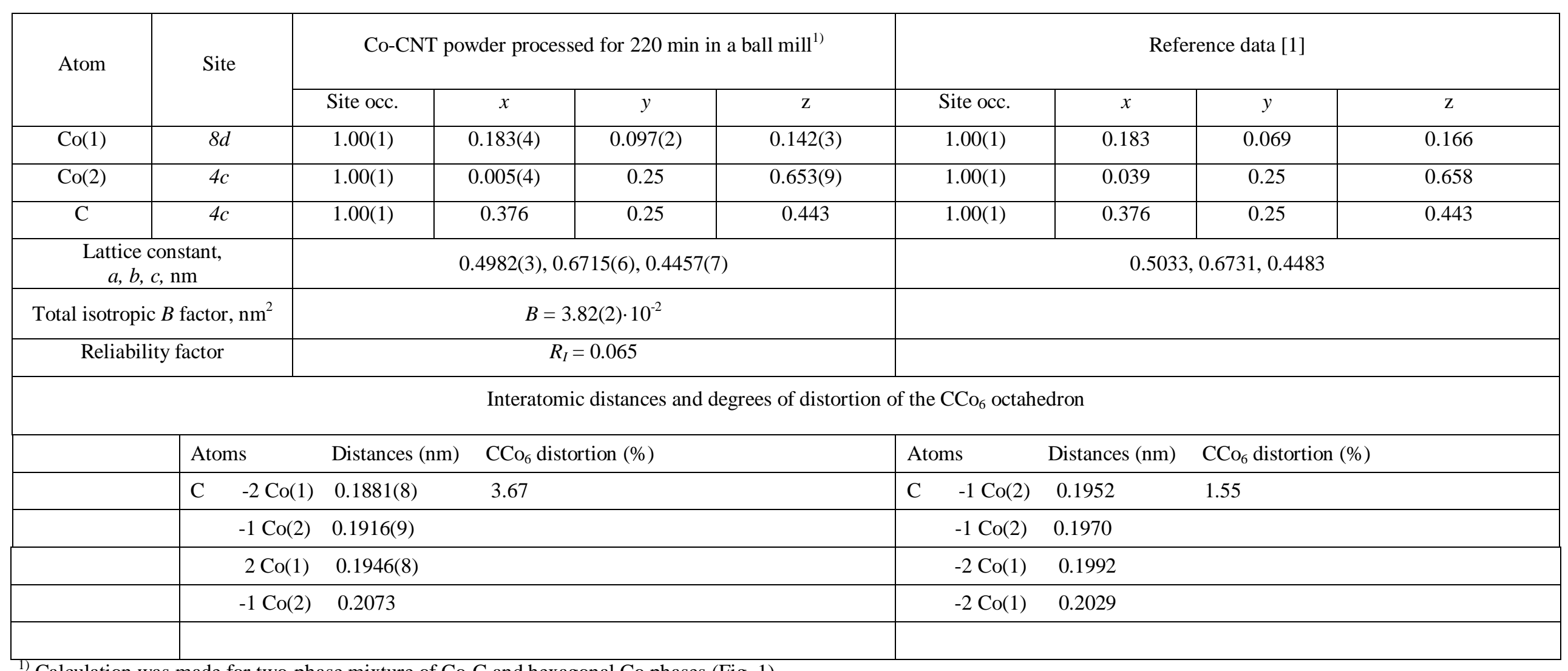

${ }^{1)}$ Calculation was made for two-phase mixture of $\mathrm{Co}_{3} \mathrm{C}$ and hexagonal Co phases (Fig. 1). 


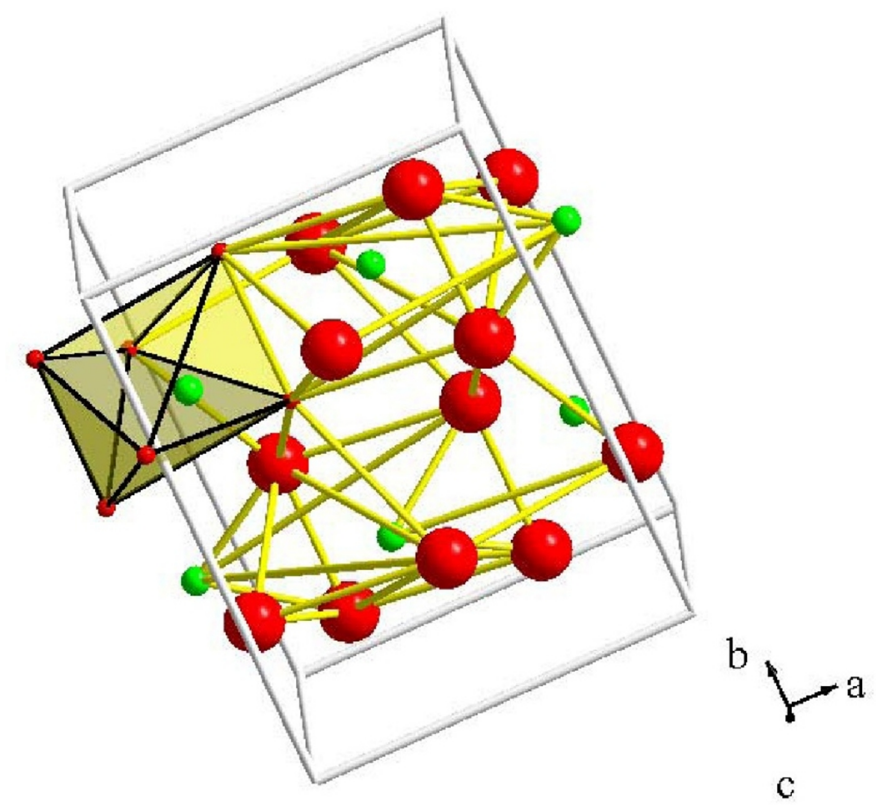

Fig. 2. Crystal structure of $\mathrm{Co}_{3} \mathrm{C}$ synthesized and $\mathrm{CCo}_{6}$ deformed octahedron (red circles are the cobalt atoms, green circles are the carbon atoms).

charge: the only reference was made to PDF data (PDF 26-0450, $a=0.4993 \mathrm{~nm}, b=0.6707 \mathrm{~nm}, c=0.4444 \mathrm{~nm}$, $V=0.148 \mathrm{~nm}^{3}$ ) when identifying this phase. However, these lattice constants are close to those obtained by us for the $\mathrm{Co}_{3} \mathrm{C}$ phase synthesized from the Co-CNT charge.

It is known that carbon atoms in compounds crystallized in the type $\mathrm{Fe}_{3} \mathrm{C}$-type structure have the octahedral surroundings of metal atoms (Fig. 2). The reference [1] and our data on the location of the atoms in the crystal structures of the $\mathrm{Co}_{3} \mathrm{C}$ carbide (Table 1) makes it possible to calculate the degrees of distortion of the $\mathrm{CCo}_{6}$ octahedron for these phases as:

$$
S, \%=\frac{100}{d}\left[\frac{\sum\left(d_{i}-d\right)^{2}}{5}\right]^{\frac{1}{2}}
$$

where $d_{i}$ is the C-Co interatomic distance and $d$ is their average value (these data are given in Table 1).

As a result of these calculations, it was shown that a significant internal distortion is inherent to the crystal structure of the $\mathrm{Co}_{3} \mathrm{C}$ carbide synthesized by the reaction milling of the Co-CNT charge. Therefore, if a degree of distortion of the $\mathrm{CCo}_{6}$ octahedron is equal to $1.55 \%$ for the $\mathrm{Co}_{3} \mathrm{C}$ carbide formed in deposited thin films [1], then it is equal to $3.67 \%$ for this compound obtained in this paper. Unfortunately, the lack of data [7] on location of the atoms in the crystal structure of the $\mathrm{Co}_{3} \mathrm{C}$ carbide obtained by mechanical alloying of the Co-graphite charge does not allow us to find out the effect of method of synthesis on the structure of this carbide.

In general, the comparison of the technological modes of reaction milling shows that the use of CNT as a component of initial mixture is more efficient for $\mathrm{Co}_{3} \mathrm{C}$ syntheses. So, while $\mathrm{Co}_{3} \mathrm{C}$ carbide is forming after $8 \mathrm{~h}$ (480 $\mathrm{min}$ ) of milling the Co-graphite charge in a ball mill [7], the use of carbon nanotubes as a component of the charge reduces this process up to 2 hours $(120 \mathrm{~min})$.

The features of the crystal structure of nanoscaled magnetic properties. Thus, previous studies of $\mathrm{Co}_{3} \mathrm{C}+$ $\mathrm{Co}_{2} \mathrm{C}$ powder mixtures showed that the value of coercive force at room temperature is equal to $100-270 \mathrm{kA} / \mathrm{m}$ and depends on both the phase composition and the dispersion of the material [7, 10]. If the synthesis conditions were modified in a consolidated material to achieve a stable value of the coercive force of $240 \mathrm{kA} / \mathrm{m}$ or higher, then the $\mathrm{Co}_{3} \mathrm{C}$ obtained by mechanochemical method could be a potential candidate for a permanent magnet materials with characteristics that correlate with the features of alnico and solid ferrites. Therefore, our further work is going to study the magnetic characteristics of this material.

\section{Conclusions}

The nanoscaled metastable $\mathrm{Co}_{3} \mathrm{C}$ carbide was synthesized by reaction milling of a mixture containing cobalt powder and multiwalled carbon nanotubes (75 at. $\%$ Co and 25 atom\% of CNT) in a high-energy planetary ball mill. The transformation of the components of the charge takes place by the reaction of hcp-Co $+\mathrm{C} \rightarrow$ $\mathrm{Co}_{3} \mathrm{C}$ (reaction time $120-220 \mathrm{~min}$ ). The crystal structure of the $\mathrm{Co}_{3} \mathrm{C}$ carbide was studied by X-ray diffraction. It was shown that the crystal structure of $\mathrm{Co}_{3} \mathrm{C}$ synthesized by the reaction milling of Co-CNT charge is significantly internally deformed (degree of deformation of the octahedron $\mathrm{CCo}_{6}$ is $3.67 \%$ ) and characterizes by reduced interatomic distances Co-C (up to $0.188 \mathrm{~nm}$ ). It is also shown that the use of carbon nanotubes as a charge component instead of graphite at mechanochemical synthesis substantially reduces the processing time of $\mathrm{Co}_{3} \mathrm{C}$ carbide. 
Nakonechna O.I. - Candidate of Sciences (Physics and Mathematics), Senior Researcher, Doctorate in Physics; Dashevskyi M.M. - Senior Engineer;
Kurylyuk A.M. - Candidate of Sciences (Physics and Mathematics), Senior Engineer, Research Fellow;

Belyavina N.N. - Candidate of Sciences (Physics and Mathematics), Senior Researcher.

[1] S. Nagakura, Journal of the Physical Society of Japan 16 (6), 1213 (1961). (doi: 10.1143/JPSJ.16.1213).

[2] B.X. Liu, J. Wang, Z.Z. Fang, Journal of Applied Physics 69 (10), 7342 (1991). (doi: 10.1063/1.347590).

[3] M. Zamanpour, S.P. Bennett, L. Majidi, Y. Chen, V.G. Harris, Journal of Alloys and Compounds 625,138 (2015) (doi: 10.1016/j.jallcom.2014.11.083).

[4] Z. Chen, L. Liu, Q. Chen, Materials Letters 164, 554 (2016). (doi: 10.1016/j.matlet.2015.11.063).

[5] L. Zhong, F. Yu, Y.An, et al. Nature 538 (84-87), 7623 (2016). (doi: 10.1038/nature19786).

[6] J.C. Mohandas, M.K. Gnanamani, G. Jacobs, et. al., ACS Catalysis, 1 (11), 1581 (2011). (doi: 10.1021/cs200236q).

[7] Yu.I. Sementsov, N.A. Gavrilyuk, G.P. Prikhod'ko, et.al., NATO Security through Science Series A: Chemistry and Biology, 757 (2007).

[8] O. Boshko, O. Nakonechna, N. Belyavina, M. Dashevskyi, S. Revo, Adv. Powder Technol., 28(3), 964 (2017). (doi: 10.1016/j.apt.2016.12.026).

[9] Z. Turgut, M.S. Lucas, S. Leontsev, S.L. Semiatin, J. Horwath, Journal of Alloys and Compounds 676, 187 (2016). (doi: 10.1016/j.jallcom.2016.03.095).

[10] V.G. Harris, Y. Chen, A. Yang, et.al., Journal of Physics D: Applied Physics, 43(16), 165003 (2010). (doi: 10.1088/0022-3727/43/16/165003).

\title{
O.I. Наконечна, М.М. Дашевський, А.М. Курилюк, Н.М. Білявина
}

\section{Механохімічний синтез карбіду кобальту з використанням вуглецевих нанотрубок}

\author{
Науково-дослідна лабораторія «Фізика металів та кераміки» Київського національного університету \\ імені Тараса Шевченка, вул. Володимирська, 64/13, м. Київ, Україна, 01601
}

\begin{abstract}
Метастабільний нанорозмірний карбід $\mathrm{Co}_{3} \mathrm{C}$ зі структурою типу $\mathrm{Fe}_{3} \mathrm{C}$ вперше синтезовано механохімічним сплавленням в високоенергетичному планетарному млині шихти, що містить порошки кобальту та багатошарових вуглецевих нанотрубок. Докладно досліджено кристалічну структуру цього карбіду і показано, що механохімічна обробка веде до іiї суттєвої внутрішньої деформації, яка проявляється як в збільшенні ступеню деформації октаедру $\mathrm{CCo}_{6}$, так і в скороченні деяких Co-C міжатомних відстаней. Показано ефективність застосування вуглецевих нанотрубок замість графіту при механохімічному синтезі карбіду $\mathrm{Co}_{3} \mathrm{C}$.
\end{abstract}

Ключові слова: багатошарова вуглецева нанотрубка, кобальт, рентгенівська дифракція, механохімічний синтез. 